\title{
A multimethodological approach to study the spatial distribution of air pollution in an Alpine valley during wintertime
}

\author{
R. Schnitzhofer ${ }^{1}$, M. Norman ${ }^{1}$, A. Wisthaler ${ }^{1}$, J. Vergeiner ${ }^{2}$, F. Harnisch ${ }^{2}$, A. Gohm ${ }^{2}$, F. Obleitner ${ }^{2}$, A. Fix ${ }^{3}$, \\ B. Neininger ${ }^{4}$, and A. Hansel ${ }^{1}$ \\ ${ }^{1}$ Institute of Ion Physics and Applied Physics, University of Innsbruck, Innsbruck, Austria \\ ${ }^{2}$ Institute of Meteorology and Geophysics, University of Innsbruck, Innsbruck, Austria \\ ${ }^{3}$ Institut für Physik der Atmosphäre, Deutsches Zentrum für Luft- und Raumfahrt (DLR), Oberpfaffenhofen, Germany \\ ${ }^{4}$ MetAir AG, Menzingen, Switzerland
}

Received: 17 November 2008 - Published in Atmos. Chem. Phys. Discuss.: 9 February 2009

Revised: 20 May 2009 - Accepted: 20 May 2009 - Published: 26 May 2009

\begin{abstract}
In order to investigate the spatial distribution of air pollutants in the Inn valley (Tyrol, Austria) during wintertime, a joint field campaign of the three research projects ALPNAP (Monitoring and Minimisation of Traffic-Induced Noise and Air Pollution Along Major Alpine Transport Routes), INNAP (Boundary Layer Structure in the Inn Valley during high Air Pollution) and INNOX $\left(\mathrm{NO}_{\mathrm{x}}\right.$-structure in the Inn Valley during High Air Pollution) was carried out in January/February 2006. In addition to continuous ground based measurements, vertical profiles of various air pollutants and meteorological parameters were obtained on six selected days. For in-situ investigations, a tethered balloon was used to analyse the lowest atmospheric layers, 0 $500 \mathrm{~m}$ above the valley bottom (a.v.b.), and a research aircraft sampled at 150-2200 ma.v.b. An aircraft equipped with an aerosol backscatter lidar performed nadir measurements at $3000 \mathrm{~m}$ a.v.b. Combined results from a typical day show a strongly polluted layer up to about $125 \mathrm{~m}$ a.v.b. in the morning. Around midday concentrations on the valley floor decrease indicating some vertical air exchange despite thermally stable conditions. Strong vertical and horizontal gradients with enhanced pollution levels along the sunny side of the valley up to $1300 \mathrm{~m}$ a.v.b. were observed in the afternoon. This vertical mixing due to thermally or dynamically driven slope winds reduces the concentration of air pollutants at the bottom of the valley and causes the formation of elevated pollution layers.
\end{abstract}

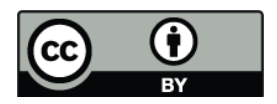

Correspondence to: A. Hansel (armin.hansel@uibk.ac.at)

\section{Introduction}

Growing mobility is associated with increasing emissions from fossil fuel burning. Many of the emitted compounds have detrimental effects on human health. The European Commission estimates the environmental costs (air pollution, noise and global warming) of overall traffic in the European Union to be $1.1 \%$ of the gross domestic product. The growth of goods transport (2.8\%) is slightly faster than the economic growth (2.3\% per year, between 1995 and 2004). Due to the increasing demand of door-to-door and just-in-time service, a disproportional large share of this growth is carried on roads (European Commission, 2006).

Being part of the Brenner route, one of the main transport routes between northern and southern Europe, the Inn- and the Wipp-valley face particularly high HDV (Heavy-DutyVehicle) traffic density. The traffic volume in the eastern Inn valley has doubled from 1980 to 2000 (Verkehrsclub Österreich, 2004) and it is predicted to increase further by about 40\% until 2012 (Thudium, 2003). Technical progress in emission reduction does not compensate for the effect of the ongoing increase of traffic density. Air quality legislation threshold values were exceeded at 6 out of $13 \mathrm{NO}_{2}$, and at 7 out of $12 \mathrm{PM}_{10}$ measurement stations in Tyrol in the year 2005 (Weber et al., 2005). Therefore, strategies to improve air quality have been implemented. The Tyrolean government introduced a HDV ban during nights and a speed limit for light duty vehicles (LDV) of $100 \mathrm{~km} / \mathrm{h}$ during the winter season (November-April) for the Inn valley motorway (A12). This is supposed to reduce emissions of $\mathrm{NO}_{\mathrm{x}}$ and $\mathrm{PM}_{10}$ by approximately $10 \%$ (Thudium, 2005; Oettl et al., 2006). 


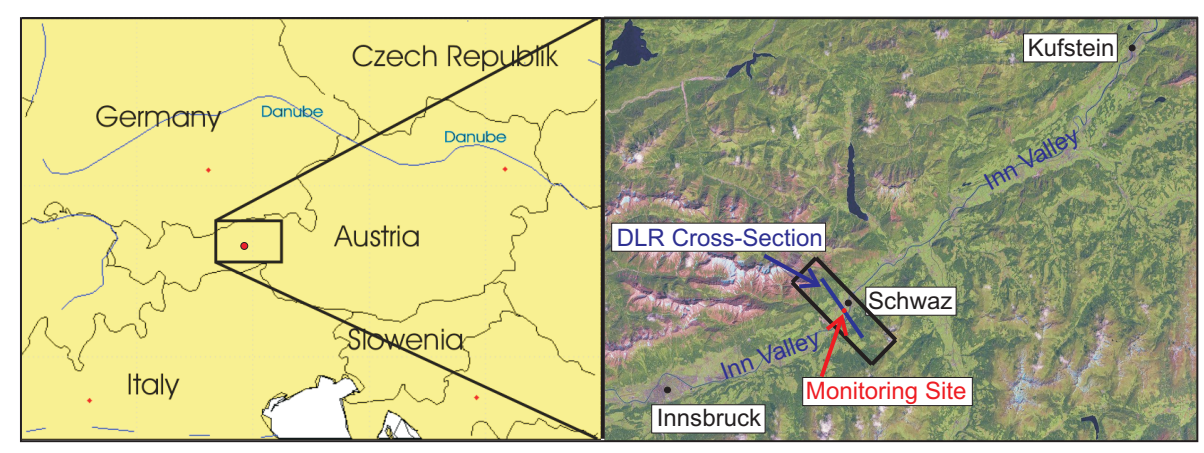

Fig. 1. Map of the measurement location in the Inn valley, Tyrol, Austria. Ground-based measurements were located near the town Schwaz at $540 \mathrm{~m}$ m.s.l. The blue line indicates the flight leg of the DLR Cessna. The flight path of the MetAir Dimona was within the black box in the right panel.

However, not only emission levels, also meteorological conditions, that control dilution and dispersion of pollutants, have a large impact on air quality, especially over complex terrain. Beside channeling the traffic into some main routes, the mountainous landscape of the Alps also forces the air flow along the valley, even though tributaries significantly influence the main valley wind system (Zaengl, 2004). In contrast to flat terrain, air pollutants can only be removed vertically and along the valley axis. Moreover the mountains reduce wind speed and favour inversion layers that restrict vertical dilution (Dreiseitl and Stöhr, 1991). A thermally driven wind system, that occurs in the Inn valley on $30 \%$ of all days (Vergeiner and Dreiseitl, 1987), can lead to a recirculation of polluted air (Grießer, 2003). Specific mountain effects cause morning $\mathrm{NO}_{\mathrm{x}}$ concentrations to be up to nine times higher in the Inn valley than over flat terrain with the same emission source strength (Wotawa et al., 2000).

Previous investigations in the Inn valley were mostly based on point measurements and dispersion models (e.g. Thudium, 2005; Oettl et al., 2006; Schnitzhofer et al., 2008). In order to proof the spatial representativeness of point measurements and to validate and improve existing models there is a need of airborne in situ measurements. During the MEMOSA-project the summertime distribution of various air pollutants was studied across the Alps on 7 flight days between 1990 and 1992 (Schlager and Graf, 1993). In the VOTALP-project that took place in the Mesoclina-valley (Switzerland) in summer 1996, airborne in situ measurements were performed to investigate advection of polluted air from the Po valley via the valley wind regime. Using a simple box model it was found, that the whole valley air volume was exchanged 3-6 times through slope and valley wind systems during fair weather conditions in summer (Carnuth and Trickl, 2000; Furger et al., 2000; Henne et al., 2004). Through these thermally driven wind systems air pollutants can even be injected into the free troposphere (Prévôt et al., 2000b; Henne et al., 2004). The same process was proposed to reduce pollutant levels in the Inn valley during summer months (Schnitzhofer et al., 2008).

In winter the vertical air exchange is minimized due to a stably stratified valley atmosphere. However, results from a wintertime field study in two Alpine valleys in France in the year 2003 indicate some vertical transport of polluted air via slope winds (Chazette et al., 2004), which is consistent with observed minima in daytime concentration in the wintertime Inn valley (e.g. Schnitzhofer et al., 2008). In addition, a positive correlation of snow cover and valley depth to inversion strength and duration was found (Chazette et al., 2004).

The aim of the three research projects INNOX $\left(\mathrm{NO}_{\mathrm{x}}-\right.$ structure in the Inn Valley during High Air Pollution), INNAP (Boundary layer structure in the Inn valley during high air pollution) and ALPNAP (Monitoring and Minimisation of Traffic-Induced Noise and Air Pollution Along Major Alpine Transport Routes; Heimann et al., 2007) was to study the wintertime boundary layer of the Inn valley during events of high air pollution. In this paper we present an overview of the obtained dataset and give a detailed three-dimensional picture of the distribution of air pollutants on 1 February 2006, which represents a typical fair, cold winter day.

\section{Experimental}

\subsection{Location and ground based measurements}

The field campaign took place in the Inn valley near the town of Schwaz, Tyrol, Austria, in January and February 2006 (Fig. 1). The monitoring station for ground-based measurements was located between Schwaz and Vomp $\left(11.69^{\circ} \mathrm{E}\right.$, $47.34^{\circ} \mathrm{N}$ ), at $540 \mathrm{~m}$ above mean sea level (m.s.l.), about $750 \mathrm{~m}$ southeast of the A12 motorway. On average 52000 vehicles per day ( $15 \%$ heavy duty vehicles) were counted on the motorway at Vomp in 2006 (Satzinger et al., 2007). At this location the valley runs from southwest to northeast, with a width of about $1.5 \mathrm{~km}$ on the floor. The mountains on 


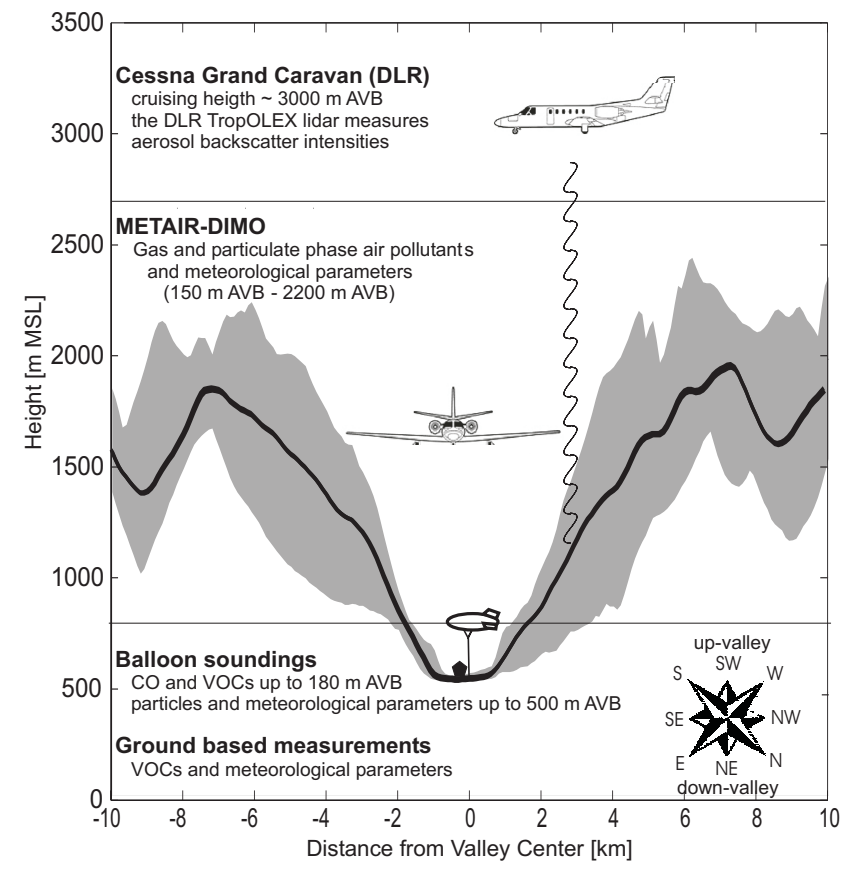

Fig. 2. Experimental setup from the joint field campaign of the research projects ALPNAP, INNAP and INNOX. The black line represents the terrain height of the average valley slopes in the $6 \times 20 \mathrm{~km}$ box plotted in Fig. 1; the shaded area represents the widest and narrowest part. The view is headed in the valley upward direction i.e. south west.

either side of the valley reach over $2500 \mathrm{~m}$ m.s.l., with a mean crest height of $2000 \mathrm{~m}$ m.s.l. and a lowest mountain pass of $1900 \mathrm{~m}$ m.s.l., within the investigation area.

Volatile organic compounds (VOCs) were measured with a Proton-Transfer-Reaction Mass-Spectrometer (PTR-MS) that has been described in detail previously (Hansel et al., 1995; Lindinger et al., 1998a,b). In addition, a meteorological station measuring radiation and temperature, pressure, wind (direction and speed), and humidity on different heights, up to $10 \mathrm{~m}$ a.v.b., was in operation. While meteorological data were gathered from October 2005 until March 2006, the PTR-MS was in use from 10 January until 14 February. On six intensive measurement days the threedimensional distribution of various air pollutants was characterised (experimental setup see Fig. 2).

\subsection{Balloon measurements}

A tethered balloon $\left(24 \mathrm{~m}^{3}\right)$ filled with helium, suitable to lift $7 \mathrm{~kg}$ of measurement equipment, was in use for soundings up to $500 \mathrm{~m}$ a.v.b. (compare Jensen et al., 2002). A sonde was fixed on the balloon measuring temperature, humidity, wind (direction and speed), and pressure. The orientation of the streamlined balloon was used to derive the wind direction. Every $10 \mathrm{~s}$ these parameters were measured and trans-
Table 1. Data gained from MetAir-Dimo measurements.

\begin{tabular}{|c|c|}
\hline Resolution & Parameter \\
\hline $10 \mathrm{~Hz}$ & $\begin{array}{l}\text { time, aircraft position, pressure, wind speed } \\
\text { and wind direction, temperature, humidity, } \\
\mathrm{CO}_{2} \text {, } \mathrm{CO} \text {, particle number concentration } \\
>0.3 \mu \mathrm{m}\end{array}$ \\
\hline $1 \mathrm{~Hz}$ & $\begin{array}{l}\text { terrain height, shortwave radiation, tem- } \\
\text { perature, humidity, } \mathrm{O}_{3}, \mathrm{NO}, \mathrm{NO}_{2} \text {, particle } \\
\text { number concentration }>0.5 \mu \mathrm{m}\end{array}$ \\
\hline $1 \mathrm{~min}$ & $\begin{array}{l}\text { particle number in } 15 \text { size bins from } 0.3 \mu \mathrm{m} \\
\text { to } 20 \mu \mathrm{m}\end{array}$ \\
\hline $10 \mathrm{~min}$ & 42 identified $\mathrm{C}_{4}$ to $\mathrm{C}_{10}$ hydrocarbons \\
\hline
\end{tabular}

mitted to the ground station. A GRIMM particle counter was in use to measure size selected particle number concentrations (15 size bins). Next to the meteorological sonde the inlet of a $200 \mathrm{~m}$ long $1 / 4^{\prime \prime}$ thin wall teflon line was mounted, which supplied air to the ground based analysing instruments (AL $5001 \mathrm{CO}$ analyser, PTR-MS). Measurements of the gaseous species were limited to about $180 \mathrm{~m}$ a.v.b., while balloon ascents without the teflon tube were conducted up to $500 \mathrm{~m}$ a.v.b. The measurement sequence was adjusted to the $10 \mathrm{~s}$ time resolution of the meteorological data. Within $10 \mathrm{~s}$ one mean value of $\mathrm{CO}$, and 10 different masses were measured with the CO analyser, and the PTR-MS, respectively. The inlet residence time was typically $23 \mathrm{~s}$ at 7 standard liter per minute pumping speed.

\subsection{Aircraft measurements}

Two research aircraft were deployed to investigate the spatial variability of air pollution in the Inn valley with in-situ and remote sensing techniques.

The Dimona research aircraft (Diamond Aircraft Dimona TTC-ECO, call sign HB-2335) from MetAir AG (Switzerland) conducted measurements from about $150 \mathrm{~m}$ a.v.b. (minimum safety flight altitude) up to $2200 \mathrm{~m}$ a.v.b. The list of obtained data is given in Table 1. The temporal resolution for the measured parameters range from $0.1 \mathrm{~s}$ to $10 \mathrm{~min}$, with the lowest temporal resolution available for the gas chromatographic (GC) data. With a typical speed of $150 \mathrm{~km} \mathrm{~h}^{-1}$ the Dimona covers a distance of about $25 \mathrm{~km}$ within $10 \mathrm{~min}$. Therefore, the GC-data have to be interpreted as average values over a larger area. Nevertheless the flight pattern of the Dimona - it stayed at a constant altitude for each GC cycle - enabled to obtain vertical profiles of more than 30 VOCs. A detailed description of the whole system is given by Neininger et al. (2001).

The second aircraft from the Deutsches Zentrum für Luftund Raumfahrt (DLR) performed downward looking aerosol backscatter lidar measurements. The TropOLEX lidar, operating in the nadir pointing mode, was installed onboard a Cessna Grand Caravan measuring backscatter intensities at 


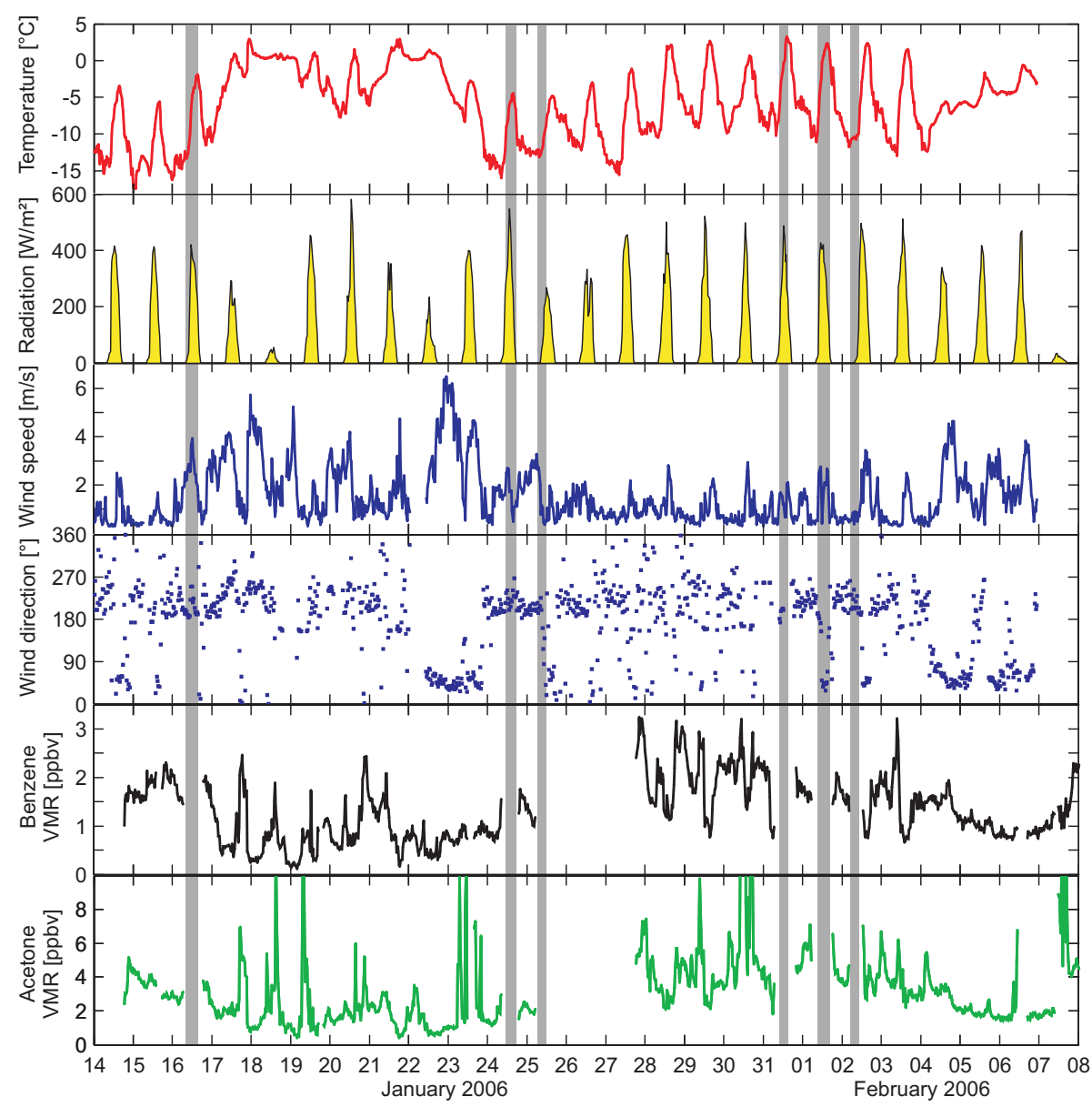

Fig. 3. Overview graph of temperature, shortwave incident radiation, wind speed and wind direction, benzene and acetone VMRs for the whole period of PTR-MS measurements near Schwaz from 14 January until 8 February 2006 (half hourly values). Grey bars indicate days when balloon soundings and aircraft measurements were performed.

wavelengths of $1064 \mathrm{~nm}$ and $532 \mathrm{~nm}$. Details about the measurement principle can be found in Meister et al. (2003). A regular flight pattern consisted of several along and acrossvalley transects at a constant altitude of about $3000 \mathrm{~m}$ a.v.b. The horizontal and vertical resolution was $45 \mathrm{~m}$ and $15 \mathrm{~m}$, respectively.

\section{Results and discussion}

\subsection{Time series of ground based measurements}

The winter 2005/2006 was cold in the Inn valley with a January mean temperature in Jenbach (about $10 \mathrm{~km}$ downvalley from the measurement site) $4.4^{\circ} \mathrm{C}$ below the average (19932002). The Inn valley bottom was snow covered from mid November with roughly $30 \mathrm{~cm}$ snow in Schwaz during the field campaign in January/February 2006.

Figure 3 shows temperature, shortwave incoming radiation, wind speed and wind direction, and the volume mix- ing ratios (VMRs) of benzene and acetone for the whole period of ground based VOC-measurements. Grey bars indicate days when balloon soundings and aircraft measurements were performed. The variations in the VOC signal are rather difficult to interpret. In some cases a diurnal pattern anticorrelated with temperature and radiation, in other situations synoptical weather systems strongly influenced pollution levels in the Inn valley, when for example a cold front passage disturbed the stable stratification of the valley atmosphere.

VOC measurements started on 14 January, right at the end of a longer period influenced by a high pressure system above southern Scandinavia, a low pressure system above Italy and therefore an easterly flow over Austria that advected cold air from eastern Europe. During this synoptic situation pollutants accumulated in the valley due to strong inversion layers that trapped pollutants close to the valley floor. The solar radiation modified the inversion layers, but was not strong enough to break them up. Benzene and acetone VMRs (see Fig. 3) were high throughout the day until 17 January. Then 


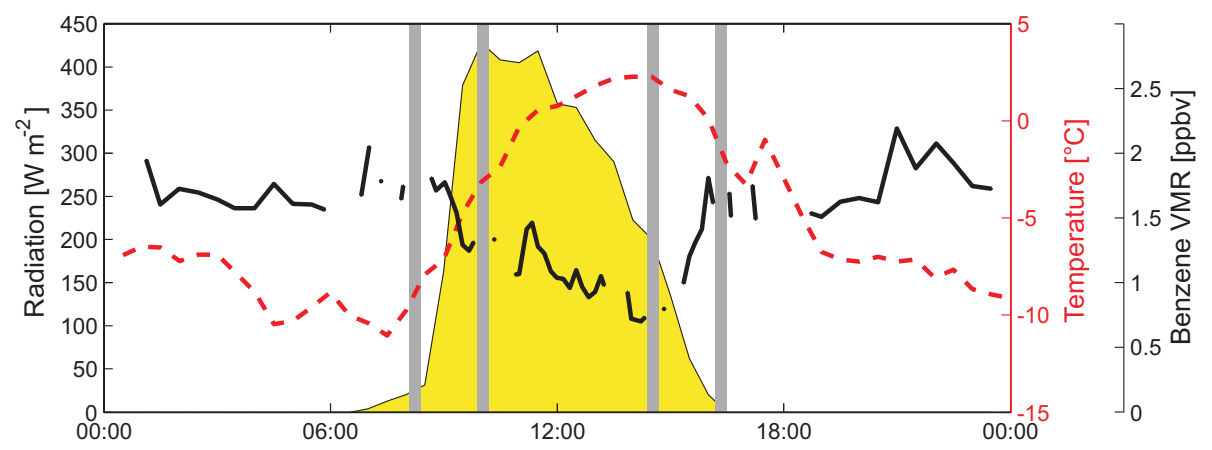

Fig. 4. Diurnal variation of ground level benzene VMR (black solid line), shortwave-incoming radiation (yellow area) and $2 \mathrm{~m}$ air temperature (red dashed line) on 1 February 2006. The grey bars indicate times when vertical profiles, plotted in Fig. 5, were measured.

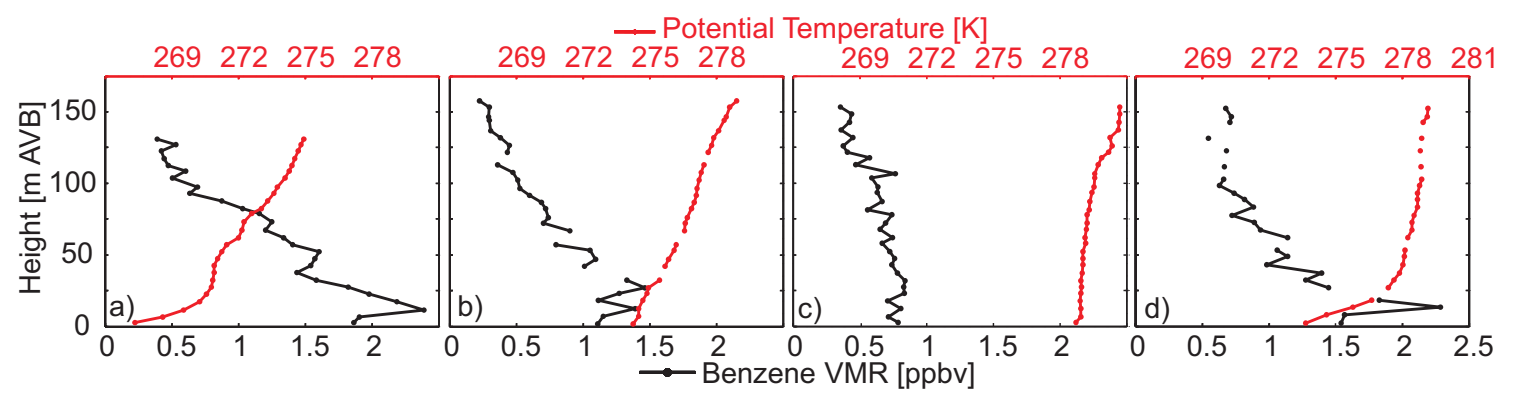

Fig. 5. Vertical profiles of benzene VMR (black) and potential temperature (red) on 1 February 2006. Data points represent average values over 5 height $m$. Profiles match with times indicated by gray bars in Fig. 4 - (a): 07:56-08:19 UTC; (b): 09:50-10:07 UTC; (c): 14:2314:51 UTC; (d): 16:10-16:22 UTC.

one week of variable conditions followed with some snowfall most intensively on 18 and 22 January. The VOC signal was highly variable, with short times of high values, due to surface temperature inversions. However, the overall VOC signal was lower because of less stable atmospheric conditions and higher wind speeds compared to the beginning of the measurement period. From 23-25 January arctic air from Northeast Europe was advected to Austria. On these days with a rather undisturbed daily temperature cycle VOC levels started to rise again. On 25 and 26 January a cut-off low moved from Finland across Switzerland to the Pyrenees and brought overcast conditions but no precipitation. From 27 January to 4 February again a high pressure system influenced the weather in Tyrol with undisturbed incoming radiation. Unfortunately, there was an instrument failure from 25 27 January, however, levels on 29 January were high again and showed diurnal variations anticorrelating with temperature and shortwave radiation until 4 February. The mean values for benzene and acetone averaged over the whole measurements period were $1.25 \mathrm{ppbv}$ and $3.1 \mathrm{ppbv}$, respectively. This exceeds values measured in Zürich in winter 2005/06 (Gaeggeler et al., 2008) by a factor of 1.8 and 2.5.

\subsection{Case study: 1 February 2006}

On 1 February 2006 the synoptic situation in the Alpine region was characterized by a high pressure system with weak winds. The solar insolation was only disturbed by some thin cirrus clouds and the associated daytime heating reduced the thermal stability in the lowest $500 \mathrm{~m}$, where a weak upvalley flow developed during the day (see Fig. 3 and compare Harnisch et al., 2008). Similar situations were frequently observed during our measurement period (compare Fig. 3).

Measurements were conducted with both aircraft in the morning as well as in the afternoon. In addition 10 vertical profiles of VOC VMRs and 4 of particle number concentration were obtained by balloon measurements.

\subsubsection{Diurnal cycle}

Figure 4 shows the diurnal variation of shortwave-incoming radiation, temperature and the benzene VMR near ground on 1 February 2006. Grey bars indicate times when vertical profiles of benzene VMR and potential temperature were measured (Fig. 5). A clear diurnal pattern in benzene levels was observed with a $\sim 2$ ppbv nighttime maximum and a $\sim 0.75$ ppbv daytime minimum. This does not coincide with 


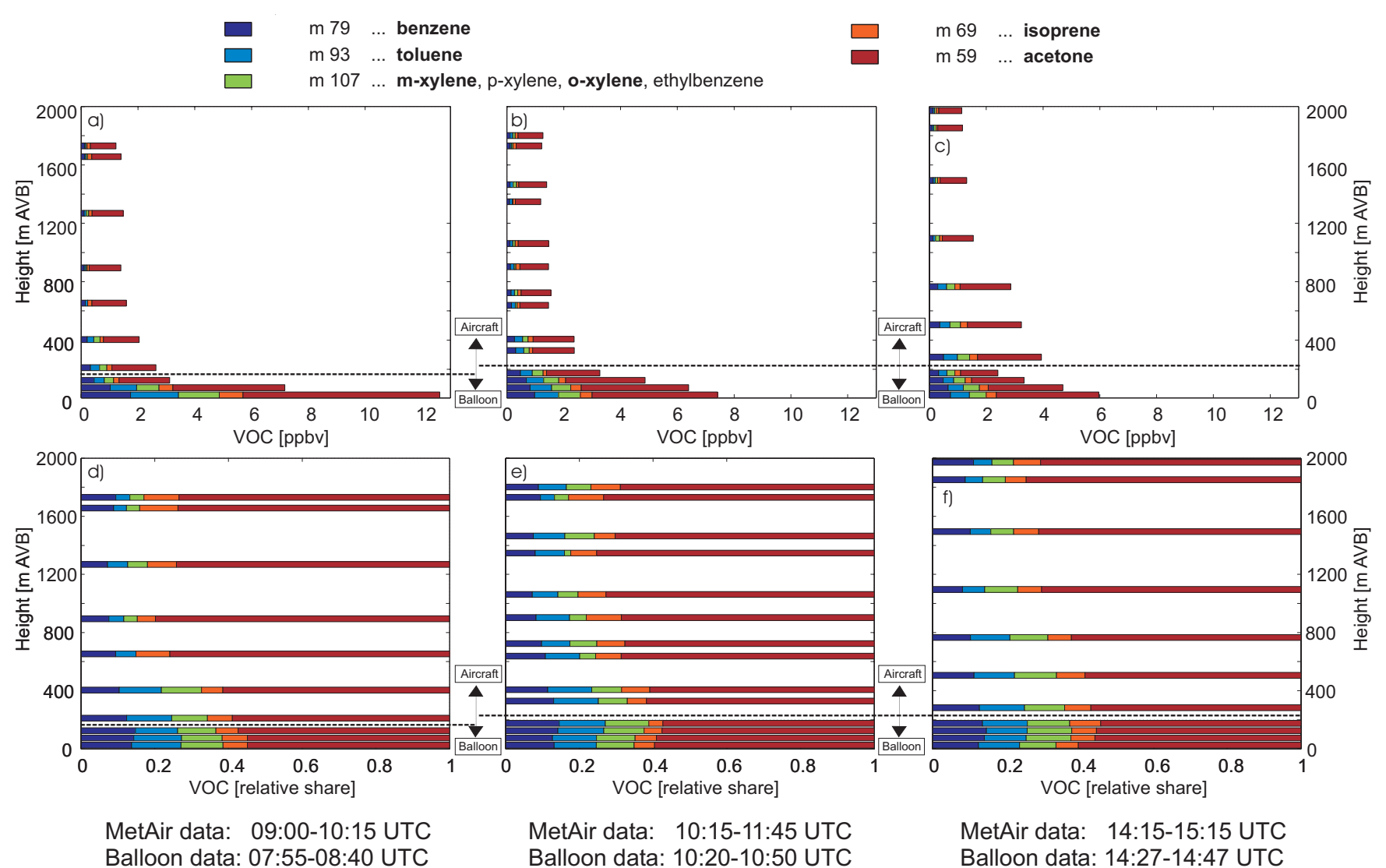

Fig. 6. Vertical profiles of VOCs measured with a PTR-MS system (balloon soundings) and an onboard GC (MetAir-Dimo). PTR-MS signals on nominal masses (m59, m69, m79, m93, m107) are calibrated with the designated main compound (bold) but also correspond to other GC-identified substances with the same mass $(\mathbf{a}-\mathbf{c})$. In (d-f) the relative share of these compounds is shown. PTR-MS data are averaged over $50 \mathrm{~m}$ altitude, while GC data were sampled over $9 \mathrm{~min}$, during which the aircraft tried to stay at the same height level.

traffic emission source strength. It indicates that meteorological parameters were mainly responsible for the diurnal variation of pollution levels by determining dispersion and dilution conditions. During night a surface inversion develops due to the radiation deficit of the surface. Near ground emitted pollutants are trapped in the stable surface boundary layer. The vertical profile at 08:00 UTC, before the sun has reached the valley floor, shows how the stable stratification prevents a vertical air exchange and how pollutants accumulate in a shallow layer (Fig. 5a). At $100 \mathrm{~m}$ a.v.b. benzene levels have already decreased by a factor of four compared to surface values. Two hours later at 10:00 UTC the low level temperature inversion is much less intense and the benzene VMR has decreased. However, there is still a significant benzene gradient within the lowermost $100 \mathrm{~m}$ a.v.b. (Fig. 5b). The benzene level near ground reaches its minimum at 15:00 UTC, when the daily temperature maximum occurs. At this time, the valley atmosphere is well mixed up to $100 \mathrm{~m}$ a.v.b. and benzene is homogenously distributed within this layer (Fig. 5c). Benzene levels on the ground increase again when the radiation balance at the surface be- comes negative. A low-level temperature inversion reduces the dilution volume and pollutant levels increase immediately (Fig. 5d). The observed diurnal variation is similar to previous observations at this location and in other Alpine valleys throughout the year (Schnitzhofer et al., 2008; Prévôt et al., 2000a). Beside this diurnal pattern governed by thermal stratification, a short and sharp increase in benzene VMR was observed at 11:00 UTC (see Fig. 4). This was caused by a short-term reversal of the valley wind system and advection of more polluted air from the lower Inn valley (compare wind data in Fig. 3).

\subsubsection{Vertical profiles of VOCs}

Figure 6 displays the vertical profiles of a series of selected VOCs as measured by PTR-MS (0-200 $\mathrm{m}$ a.v.b., ballon) and GC (150-2200 m a.v.b., aircraft). All GC measured compounds that can not be separated with a PTR-MS (the xylene isomers and ethylbenzene have the same nominal mass) were summed up. PTR-MS data were vertically averaged over $50 \mathrm{~m}$ for this plot. 

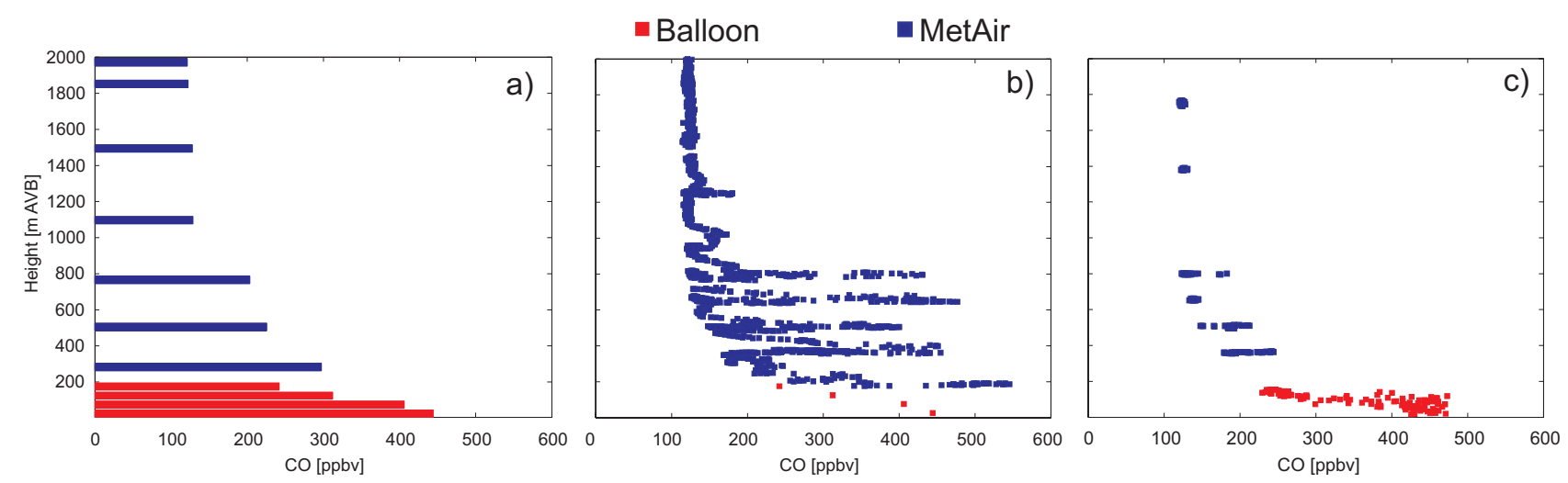

Fig. 7. Vertical profiles of $\mathrm{CO}$ obtained from balloon and aircraft measurements. (a) shows balloon data (red) averaged over 50 height $\mathrm{m}$ and aircraft data averaged over $10 \mathrm{~min}$ (blue). (b) shows balloon data averaged over 50 height $\mathrm{m}$ and $1 \mathrm{~Hz} \mathrm{CO}$ data. In (c) the balloon data are averaged over $10 \mathrm{~s}$ and from the $1 \mathrm{~Hz}$ aircraft data only those in vicinity (600 m north-south; $6.5 \mathrm{~km}$ east-west) of the balloon location are plotted.

In the morning (between 07:55 and 10:15 UTC) the VOC concentration near the ground was about 5 times higher compared to levels above $200 \mathrm{~m}$ a.v.b. (Fig. 6a). In Fig. 6d the corresponding relative fraction of the selected compounds is plotted. Aircraft and balloon data are in excellent agreement, both in absolute and relative values. The relative portion of acetone increased with height, due to its compared to the other compounds, longer atmospheric lifetime and therefore higher tropospheric background concentration. The stable valley atmosphere trapped freshly emitted pollutants near the ground and separated them from the chemically aged air aloft.

Around midday (between 10:15 and 11:45 UTC) pollutants were redistributed in the lowest air layers due to the break-up of the surface inversion. There was still a vertical gradient but levels near ground had decreased while levels from 100 up to $500 \mathrm{~m}$ a.v.b. had increased. Again, the agreement between the two measurement systems was very reasonable (Fig. $6 \mathrm{~b}$ and e).

In the afternoon (between 14:15 and 15:15 UTC) a further decrease of VOC VMRs near the ground, and an increase from $200 \mathrm{~m}$ up to $1000 \mathrm{~m}$ a.v.b. was observed. Compared to the morning values the VMR of some compounds have increased by a factor of two. This is similar to the diurnal variation of VOCs in higher air layers observed in the Swiss Alps during summertime (Prévôt et al., 2000b), where increased VOC values could be found up to $4000 \mathrm{~m}$ m.s.l. during undisturbed clear weather conditions. While the relative share of the measured VOCs was similar for balloon and aircraft measurements (Fig. 6f), discrepancies occurred in absolute values, with lower concentrations for the balloon soundings than for the aircraft measurements (Fig. 6c). This difference can be explained by the different spatial footprint areas of the measurements. The balloon soundings provided one vertical profile in the middle of the valley, while the aircraft data represent an average over the whole valley width at one particular altitude. Whereas during morning hours pollutants were more homogeneously distributed, in the afternoon differences between the sunny and the shaded side of the valley occurred. This becomes evident in the high time resolution $\mathrm{CO}$ measurements (Fig. 7b and Sect. 3.2.4). When averaging the $\mathrm{CO}$ data over $10 \mathrm{~min}$ (corresponding to one GC cycle), the profile looks similar to the VOC profile, with lower values for the balloon data than for the aircraft measurements (compare Figs. 7a and 6c between 200-300 m a.v.b.). However, if only $\mathrm{CO}$ data in the vicinity to the balloon $(600 \mathrm{~m}$ northsouth and $6.5 \mathrm{~km}$ east-west distance) location were used a homogenous profile was found (Fig. 7c).

\subsubsection{Vertical particle measurements}

In contrast to the balloon and aircraft VOC measurements, for the particle measurements the same instrument, a GRIMM counter, was used on both platforms. Due to lower concentrations aloft a longer time integration was used for the aircraft measurements ( 1 min compared to $10 \mathrm{~s}$ of the balloon). For comparison, the aircraft GRIMM data were selected $\pm 500 \mathrm{~m}$ cross valley distance from the balloon (i.e. all data between $500 \mathrm{~m}$ northwest and $500 \mathrm{~m}$ southeast from the balloon). For the temperature measurement this distance was reduced to $\pm 100 \mathrm{~m}$, due to its $1 \mathrm{~Hz}$ resolution. In Fig. 8 the particle mass concentrations from $0.3-1 \mu \mathrm{m}$ (calculated from the sum of the 5 smallest available GRIMM size bins assuming a density of $2800 \mathrm{~kg} \mathrm{~m}^{-3}$ for the particles; PM1) are plotted together with the potential temperature.

Morning data (see Fig. 8a-b) show stable conditions throughout the whole valley. Beside the surface inversion, further inversion layers appeared at 150 and at $300 \mathrm{~m}$ a.v.b. These temperature inversions restricted the vertical air exchange and caused strong gradients in the particle mass 

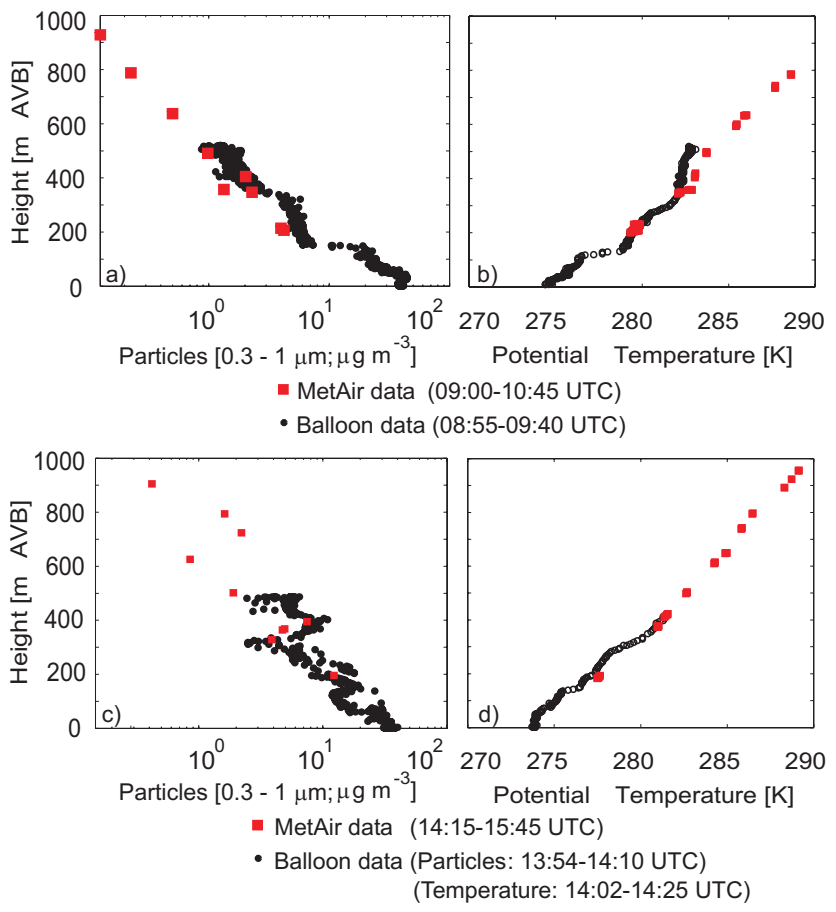

Fig. 8. Comparison of Balloon and MetAir-Dimo particle (GRIMM) and temperature measurements in the morning (a-b) and in the afternoon (c-d) on 1 February 2006. Particle mass concentrations from $0.3-1 \mu \mathrm{m}(\mathrm{a}, \mathrm{c})$; and potential temperature $(\mathrm{c}-\mathrm{d})$ are shown.

concentration. The more polluted air underneath was separated from the cleaner air aloft. Aircraft data are in good agreement with balloon measurements but do not resolve the detailed vertical structure, due to the chosen flight pattern and the lower temporal resolution. The bigger size bins (not plotted here) show the same distribution but were close to or below the detection limit.

In the afternoon the situation was even more complex (see Fig. 8c-d). The potential temperature profile shows the break up of the surface inversion and a mixed layer in the lowermost $80 \mathrm{~m}$ a.v.b., which was topped by an inversion layer. In that height a strong decrease in the particle mass concentration occurred. Below the inversion at $150 \mathrm{~m}$ a.v.b., which weakened since the morning, an increase in the particle mass concentration was observed. A second and third local maximum in the particle mass concentration occurred at 400 and $750 \mathrm{~m}$ a.v.b. This is discussed further in Sect. 3.2.5. Again balloon and aircraft data match very well and the high spatial resolution of the balloon measurements is essential to resolve the detailed structure.

\subsubsection{Valley cross section}

An even more detailed picture of the spatial distribution of air pollutants in the valley atmosphere was obtained from $1 \mathrm{~Hz}$ aircraft in situ measurements. In Fig. 9a-c the $1 \mathrm{~Hz} \mathrm{CO}$ data from the MetAir-Dimo are plotted together with data from the balloon soundings in the morning, around midday, and in the afternoon of 1 February 2006. Figure $9 d-f$ show the $\mathrm{NO}_{2}$ distribution, Fig. $9 \mathrm{~g}-\mathrm{i}$ the $\mathrm{O}_{3}$ distribution. $\mathrm{NO}_{2}$ and $\mathrm{O}_{3}$ were not measured on the balloon. In the morning (Fig. 9a) there was a strong gradient due to the low level temperature inversion close to the ground with levels about 4 times lower at $150 \mathrm{~m}$ a.v.b. than on the valley floor (for details compare benzene data; Fig. 5a). Already early in the day, the aircraft measurements show horizontal differences below $500 \mathrm{~m}$ a.v.b., with $\mathrm{CO}$ and $\mathrm{NO}_{2} \mathrm{VMRs}$ being twice as high along the sunny slope of the valley compared to the shaded one. Aloft levels represent the background concentration and no gradients were observed. Around midday (Fig. 9b and e) pollutants near ground were redistributed as described in Sect. 3.2.2. Again, highest $\mathrm{CO}$ levels occurred near the sunny slopes. In the afternoon (Fig. 9c and f) the picture gets even more asymmetric. Extended levels of $\mathrm{CO}$ and $\mathrm{NO}_{2}$ were found up to $1300 \mathrm{~m}$ a.v.b. and values at $800 \mathrm{~m}$ a.v.b. near the sunny slope were comparable with those near the ground. Background levels at the shaded side of the valley were found down to $500 \mathrm{~m}$ a.v.b. At $1000 \mathrm{~m}$ a.v.b. the CO VMRs were almost four times higher than on the shaded side of the valley. An opposite distribution was found in the $\mathrm{O}_{3}$ concentration (Fig. 9g-i). Wherever $\mathrm{NO}_{2}$ was high $\mathrm{O}_{3}$ was low because of NO titration. The asymmetric distribution was most likely caused by a vertical transport of pollutants via upslope winds. However, this circulation was not directly detected by aircraft wind measurements. This suggests the presence of a very thin upslope wind layer in which pollutants were lifted and from where they were then advected towards the middle of the valley. This horizontal transport underneath strong inversions explains the layer structure discussed in Sect. 3.2.3. The development of the slope wind layer at the sunny side of the valley was favored by snowfree treetops along the sun exposed slope.

\subsubsection{In situ particle measurements vs. lidar data}

A very detailed picture of the spatial distribution of particles was obtained from the DLR lidar measurements, which give backscatter intensity at $1064 \mathrm{~nm}$. In Fig. 10 lidar measurements are compared with MetAir-Dimo and balloon in situ measurements of particles larger than $0.3 \mu \mathrm{m}$ in the afternoon of 1 February 2006. The aerosol distribution was strongly asymmetric and small scale structured. In the lowest $200 \mathrm{~m}$ a.v.b. a minimum of backscatter intensity was observed in the middle of the valley, with slightly higher values along the shaded slopes up to about $300 \mathrm{~m}$ a.v.b. and elevated values along the sunny slope up to $1300 \mathrm{~m}$ a.v.b. Here, the aerosol concentration for particles larger than $0.3 \mu \mathrm{m}$ is almost 150 particles per $\mathrm{cm}^{3}$. In addition to the polluted slope layer 3 aerosol layers spread out horizontally from the sun-exposed slope towards the valley center. Layers 1 and 


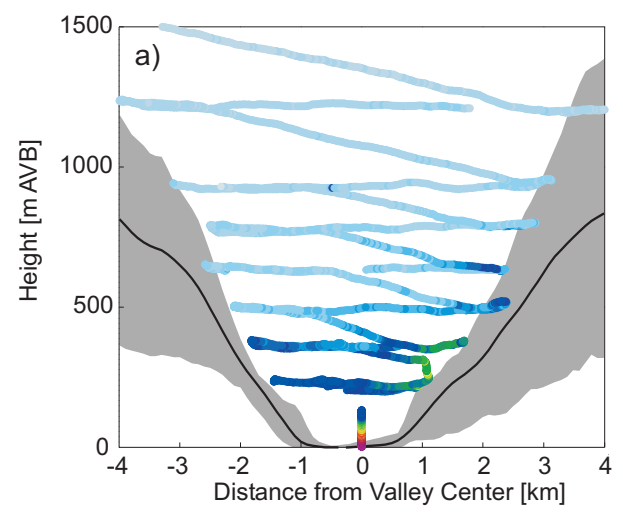

MetAir data: 09:00-10:15 UTC Balloon data: 07:55-08:40 UTC
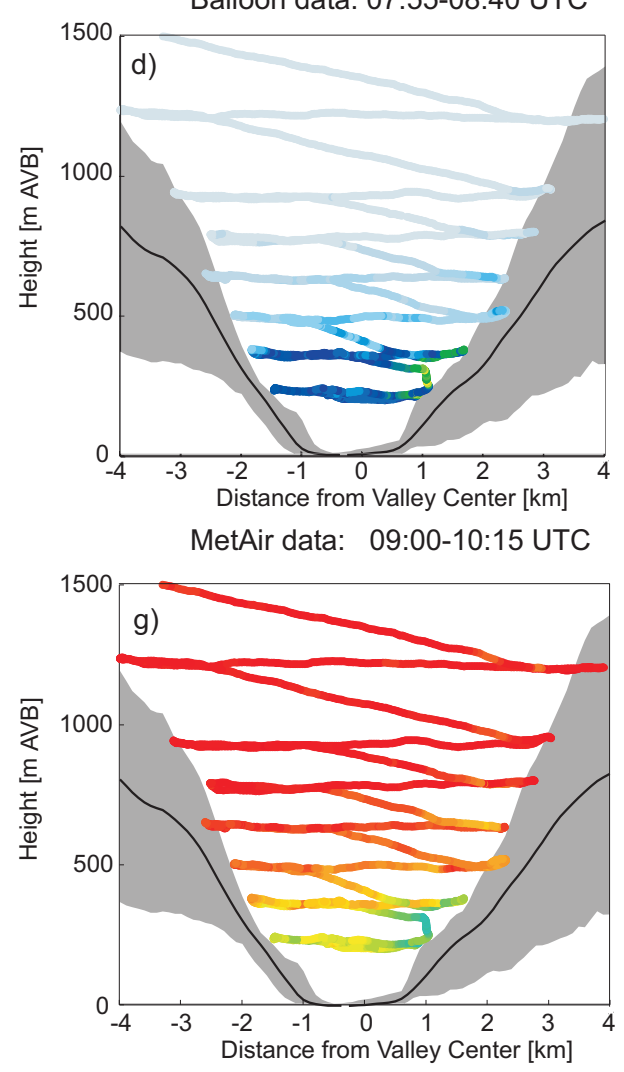

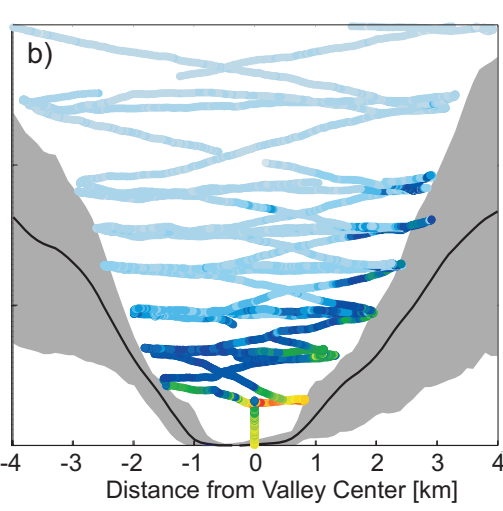

MetAir data: 10:15-11:45 UTC

Balloon data: 10:20-10:50 UTC

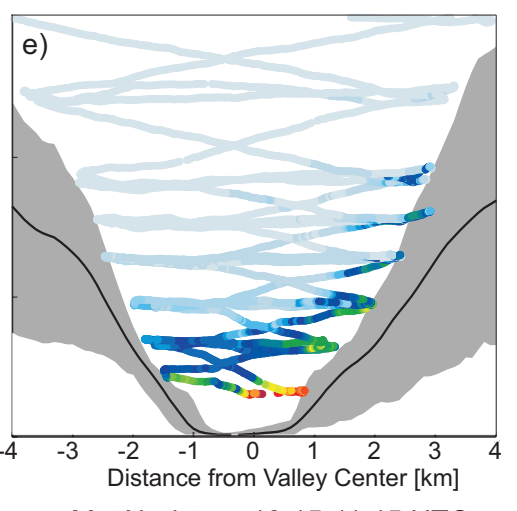

MetAir data: 10:15-11:45 UTC

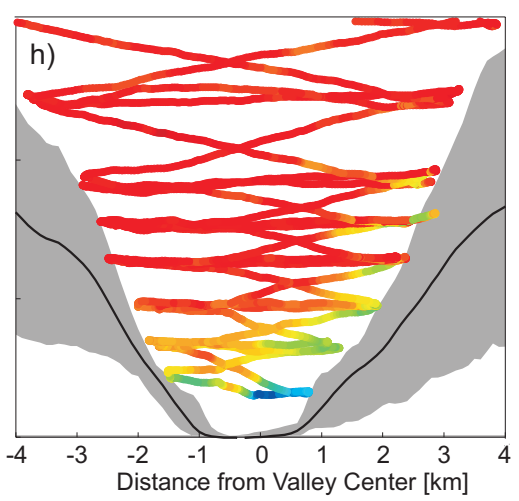

$\mathrm{CO}$ [ppbv]

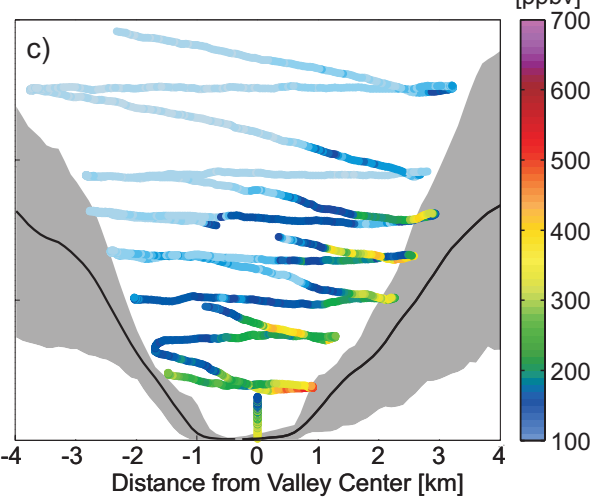

MetAir data: 14:15-15:15 UTC Balloon data: 14:27-14:47 UTC
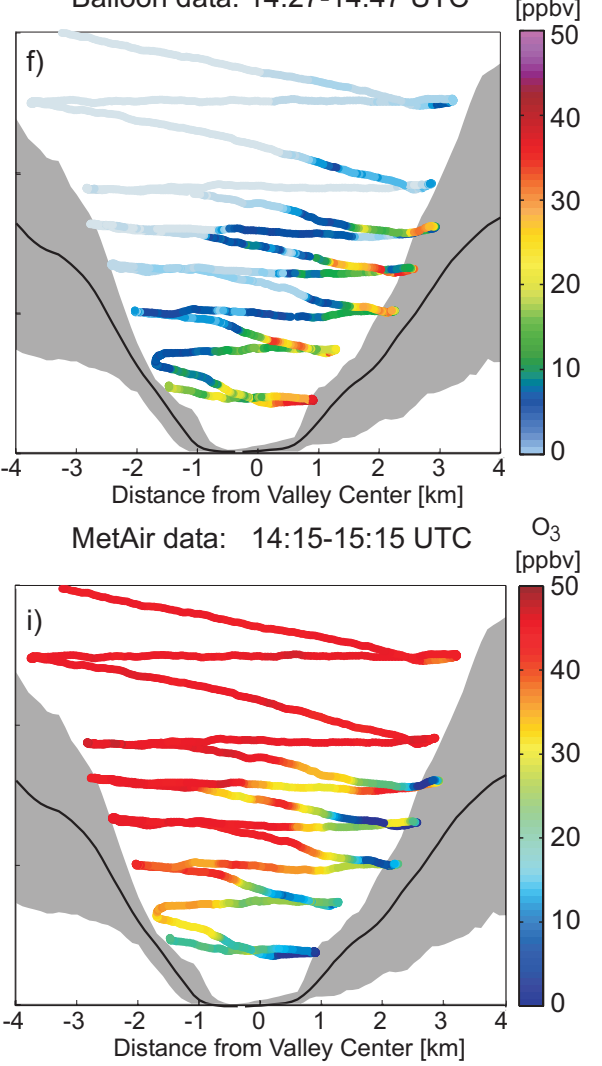

Fig. 9. Vertical transect of CO VMR across the Inn Valley near the town Schwaz in the morning (a), around midday (b) and in the afternoon (c) on 1 February 2006. (d-f) show the $\mathrm{NO}_{2}$, and $(\mathbf{g}-\mathbf{i})$ the $\mathrm{O}_{3}$ distribution for these times. The black line represents the terrain height of the average valley slopes in the $6 \times 20 \mathrm{~km}$ box plotted in Fig. 1; the shaded area represents the widest and narrowest part. The view is headed in the valley upward direction i.e. south west.

2 at 400 and $750 \mathrm{~m}$ a.v.b., respectively were also detected in particle profile measurements (compare Sect. 3.2.3). Again, a horizontal transport at the height of the inversion layers as proposed by Vergeiner and Dreiseitl (1987) was observed (compare also Fig. 8). The asymmetric distribution in the afternoon was also observed on other days (Gohm et al., 2009). The export of air pollutants from the valley into the free tro- posphere could not be quantified with this experimental setup but is expected to be small on 1 February 2006, since the vertical transport did not significantly overshoot the main crest and a reverse of the slope wind circulation after sunset partly transported the polluted air back to the valley bottom (Harnisch et al., 2008). However, a significant export of air pollutants might occur during situations with even more active 

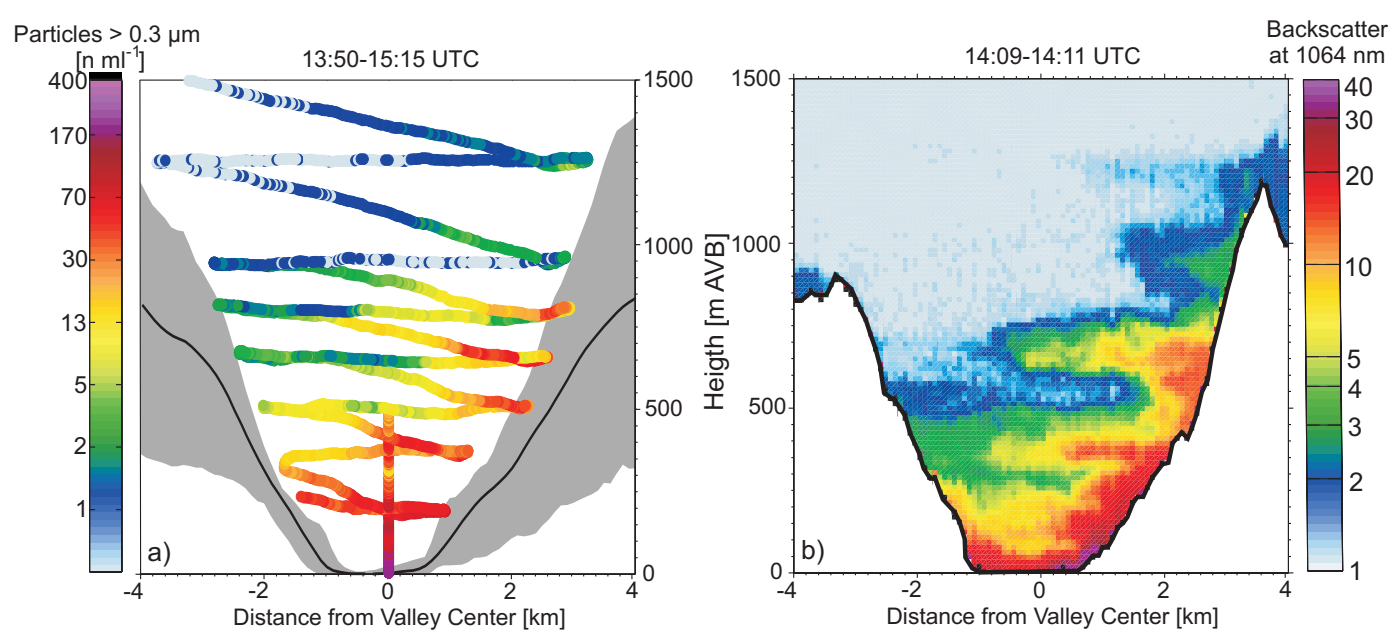

Fig. 10. Vertical transect of MetAir-Dimo and balloon in situ particle measurement (a) and DLR remote sensing lidar measurements (b) in the afternoon of 1 February 2006. Backscatter intensities at $1064 \mathrm{~nm}$ (arbitrary units) and particles larger than $0.3 \mu \mathrm{m}\left(\mathrm{n} \mathrm{ml}{ }^{-1}\right.$ ) were measured by TropOLEX-lidar and aircraft-MetOne-laser/balloon GRIMM, respectively. The black line in the left panel represents the terrain height of the average valley slopes in the $6 \times 20 \mathrm{~km}$ box plotted in Fig. 1; the shaded area represents the widest and narrowest part. The view is headed in the valley upward direction i.e. south west. In the right panel the black line represents the terrain hight across the DLR transect (see Fig. 1)

slope winds and stronger winds above crest height (Gohm et al., 2009, compare 24 January 2006), via a process described by Henne et al. (2004).

\section{Conclusions}

The three dimensional distribution of air pollutants was studied in the eastern Inn valley near the town of Schwaz during wintertime 2006. Airborne in situ and remote sensing measurements were conducted in addition to ground based measurements.

Ground based VOC data obtained by a PTR-MS instrument between 14 January and 10 February 2006 showed highest values whenever a prolonged period of fair winter weather led to a stably stratified valley atmosphere with multiple strong inversion layers below which pollutants were trapped and accumulated over days. Under these conditions a diurnal pattern was observed with a daytime minimum due to incident radiation that partly eroded the surface inversion.

Data from tethered balloon soundings gave insight into the diurnal variability of the lowest $180 \mathrm{~m}$ a.v.b. A strong surface inversion was responsible for a shallow, strongly polluted layer in the morning. During the day this inversion broke up and pollutants were homogenously distributed within the lowest $100 \mathrm{~m}$ a.v.b., with decreased levels near the ground and increased levels further aloft. After sunset air pollutant concentrations started to increase again in the lowermost air layers as the surface inversion developed again.

Aircraft measurements extended the vertical profile from about $150 \mathrm{~m}$ a.v.b. up to crest height. Aircraft and balloon data taken in the small overlap of $\mathrm{CO}$ and VOC measurements and the broader one for particle and meteorological data were in good agreement. Due to the high temporal resolution of some aircraft measurements not only vertical but also horizontal differences were observed. While in the morning minor horizontal gradients occurred, the distribution got asymmetric in the afternoon, with higher concentration along the sun-exposed slopes up to $1300 \mathrm{~m}$ a.v.b. Upward transport was found to take place in a shallow slope wind layer. This flow was observed to split at the height of strong inversion layers and to partially advect the polluted air towards the middle of the valley. This mixing process became most obvious in the lidar data, which provided the best spatial coverage but did not give absolute particle number concentration. Three layers with high backscatter intensities reaching from the sunny slope to the middle of the valley were identified on 1 February 2006. This multiple stratification that was also observed during balloon particle profiling, seems to occur frequently during fair winter weather as it was also observed on other measurement days (e.g. 24 January 2006).

The experiment provided a dataset that covers the entire valley atmosphere in a cross transect. Although data with low temporal resolution provided valuable information on the vertical distribution, fast measurements were essential to understand the complex transport mechanisms in an Alpine valley. Balloon soundings of the lowest part of the atmosphere resolved the strong gradients and the high variability of air pollutants. 
The obtained data confirm the great impact of meteorological conditions on air quality in the Inn valley. Strong inversion layers, low wind speeds and recirculation of polluted air via thermally driven winds lead to prolonged periods of high air pollutant levels. Despite the stable stratification of the valley atmosphere, a vertical transport of air pollutants via slope winds reduces their concentration at the bottom of the valley, causes the formation of elevated pollution layers and even exports pollutants from the valley during specific situations in wintertime.

In further work this dataset has been used for the validation of mesoscale transport and particle dispersion models (Lehner and Gohm, 2009) and detailed studies of the mechanism of air pollution transport (Gohm et al., 2009). A comparison between in situ particle and lidar measurements can be found in Harnisch et al. (2008).

Acknowledgements. We would like to thank A. Krismer and K. Schäfer from IMK-IFU, as well as J. Dunkl and E. Grießer from the University of Innsbruck for their support in conducting the measurements. This work was funded by the European Fleet for Airborne Research (EUFAR), the University of Innsbruck, and the European Union through the INTERREG IIIB Alpine Space Programme.

Edited by: U. Pöschl

\section{References}

Carnuth, W. and Trickl, T.: Transport studies with the IFU threewavelength aerosol lidar during the VOTALP Mesoclina experiment, Atmos. Environ., 34, 1425-1434, 2000.

Chazette, P., Couvert, P., Randriamiarisoa, H., Sanak, J., Bonsang, B., Moral, P., Berthier, S., Salanave, S., and Toussaint, F.: Threedimensional survey of pollution during winter in French Alps valleys, Atmos. Environ., 39, 1035-1047, 2004.

Dreiseitl, E. and Stöhr, D.: Zusammenhänge zwischen Emission - Meteorologie - Immission, in: Auswirkungen des Straßenverkehrs auf die Umwelt - Teilberich Luft/Vegetation/Boden, Bericht an den Tiroler Landtag, 33-38, 1991.

European Commission: Keep europe moving - Sustaiable mobility for our continent, available at: http://ec.europa.eu/transport/ transport_policy_review/doc/2006_3167_brochure_en.pdf (last access: 6 February 2009), 2006.

Furger, M., Dommen, J., Graber, W. K., Poggio, L., Prévôt, A. S. H., Emeis, S., Grell, G., Trickl, T., Gomiscek, B., Neininger, B., and Wotawa, G.: The VOTALP Mesoclina Valley Campaign $1996-$ concept, background and some highlights, Atmos. Environ., 34, 1395-1412, 2000.

Gohm, A., Harnisch, F., Obleitner, F., Vergeiner, J., Schnitzhofer, R., Hansel, A., Fix, A., Neininger, B., and Emeis, S.: Air pollution transport in an Alpine valley: Results from airborne and ground-based observations, Bound-Lay. Meteorol., accepted, doi:10.1007/s10546-009-9371-9, 2009.

Gaeggeler, K., Prévôt, A. S. H, Dommen, J., Legreid, G., Reimann, S., and Baltensberger, U.: Residential wood burning in an Alpine valley as a source for oxygenated volatile organic compounds, hydrocarbons and organic acids, Atmos. Environ., 42, 82788287, 2008.

Grießer, E.: Quantitative Simulation des $\mathrm{NO}_{\mathrm{x}}{ }^{-}$ Konzentrationsverlaufes während der Belastungsepisode im November/Dezember 1999, Master's thesis, Universität Innsbruck, 2003.

Hansel, A., Jordan, A., Holzinger, R., Prazeller, P., Vogel, W., and Lindinger, W.: Proton transfer reaction mass spectrometry: online trace gas analysis at the ppb level, Int. J. Mass. Spectrom., 149, 609-619, 1995.

Harnisch, F., Gohm, A., Fix, A., Schnitzhofer, R., Hansel, A., and Neininger, B.: Spatial distribution of aerosols in the Inn Valley atmosphere during wintertime, Meteorol. Atmos. Phys., 103, 223-235, doi:10.1029/2006GL028325, 2008.

Heimann, D., de Franceschi, M., Emais, S., Lercher, P., and Seibert, P.: Air Pollution, Traffic Noise and Related Health Effects in the Alpine Space: A Guide for Authorities and Consulters, Universita degli Studi di Trento, Dipartimento di Ingegneria Civile e Abientale, Trento, Italy, available at: http://www.alpnap.org/ results.html (last access: 5 February 2009), 2007.

Henne, S., Furger, M., Nyeki, S., Steinbacher, M., Neininger, B., de Wekker, S. F. J., Dommen, J., Spichtinger, N., Stohl, A., and Prévôt, A. S. H.: Quantification of topographic venting of boundary layer air to the free troposphere, Atmos. Chem. Phys., 4, 497509, 2004, http://www.atmos-chem-phys.net/4/497/2004/.

Henne, S., Furger, M., and Prévôt, A. S. H.: Climatology of Mountain VentingInduced Elevated Moisture Layers in the Lee of the Alps, J. Appl. Meteorol., 44, 620-633, 2005.

Jensen, M., Wisthaler, A., Hansel, A., Persson, P. O. G., and Templeman, B.: Real-time profile of organic trace gases in the Arctic boundary layer obtained during the Arctic Ocean Expedition (AOE-2001), 15th Conference on Boundary Layer and Turbulence, Wageningen, The Netherlands, 15-19 July 2002.

Lehner, M. and Gohm, A.: Idealized Simulations of Daytime Pollution Transport in a Steep Valley and its Sensitivity to Thermal Stratification and Surface Albedo, Bound-Lay. Meteorol., under review, 2009.

Lindinger, W., Hansel, A., and Jordan, A.: On-line monitoring of volatile organic compounds at pptv levels by means of ProtonTransfer-Reaction Mass Spectrometry (PTR-MS) Medical applications, food control and environmental research, Int. J. Mass. Spectrom., 173, 191-241, 1998a.

Lindinger, W., Hansel, A., and Jordan, A.: Proton-transfer-reaction mass spectrometry (PTR-MS): on-line monitoring of volatile organic compounds at pptv levels, Chem. Soc. Rev., 27, 347-354, 1998b.

Meister, A., Fix, A., Flentje, H., Wirth, M., and Ehret, G.: TropOLEX: A New Tuneable Airborne Lidar System for the Measurement of Tropospheric Ozone, in: 6th International Symposium on Tropospheric Profiling, Leipzig, 14-20 September 2003, 233-235, 2003.

Neininger, B., Fuchs, W., Baeumle, M., and Volz-Thomas, A.: A small aircraft for more than just ozone: MetAir's "Dimona" after ten years of evolving development, Proceedings of the 11th Symposium on Meteorological Observations and Instrumentation, Albuquerque, NM, USA, 14-19 January 2001, 123-128, 2001. 
Oettl, D., Hausberger, S., Rexeis, M., and Sturm, P.: Simulation of traffic induced $\mathrm{NO}_{\mathrm{x}}$-concentrations near the A12 highway in Austria, Atmos. Environ., 40, 6043-6052, 2006.

Prévôt, A. S. H., Dommen, J., Bäumle, M. and Furger M.: Diurnal variations of volatile organic compounds and local circulation systems in an Alpine valley, Atmos. Environ., 34, 1413-1423, 2000a.

Prévôt, A. S. H., Dommen, J., and Bäumle, M.: Influence of road traffic on volatile organic compound concentrations in and above a deep Alpine valley, Atmos. Environ., 34, 4719-4726, $2000 \mathrm{~b}$.

Satzinger, L., Allinger-Csollich, E., Kammerlander, S., Knoflach, O., Lintner, A., Moser, E., Porcham, J., and Schmutzhard, L.: Verkehr in Tirol - Bericht 2006, available at: http: //www.tirol.gv.at/fileadmin/www.tirol.gv.at/themen/verkehr/ service/publikationen/downloads/VB2006-internet-gesamt2.pdf (last access: 5 February 2009), 2007.

Schlager, H. and Graf, J.: Projekt MEMOSA (Messungen und Modellierung des Schadstoffverhaltens im Alpenraum), Sonderdruck der DLR im Auftrag des Bayerischen Staatsministeriums für Landesentwicklung und Umweltfragen, des Amtes der Tiroler Landesregierung und der Autonomen Provinzen Bozen und Trento, 1-20, 1993.

Schnitzhofer, R., Beauchamp, J., Dunkl, J., Wisthaler, A., Weber, A., and Hansel, A.: Long-Term Measurements of CO, $\mathrm{NO}, \mathrm{NO}_{2}$, Benzene, Toluene and $\mathrm{PM}_{10}$ at a Motorway Location in an Austrian Valley, Atmos. Environ., 42(5), 1012-1024, doi:10.1016/j.atmosenv.2007.10.004, 2008.

Thudium, J.: Szenarien der Entwicklung des Schweren Güterverkehrs 2002-2012, Auswirkungen des Nachtfahrverbots auf der A12 Oktober 2002-Jänner 2003, Ökoscience, im Auftrag der Tiroler Landesregierung, available at: http: //www.tirol.gv.at/fileadmin/www.tirol.gv.at/themen/umwelt/ luftwqualitaet/downloads/szenarien-feber2003-endv2.pdf (last access: 5 February 2009), 2003.
Thudium, J.: Lufthygienische Situation im Unterinntal 2004, Ökoscience, im Auftrag der Tiroler Landesregierung, available at: http://www.tirol.gv.at/fileadmin/www. tirol.gv.at/themen/verkehr/verkehrsplanung/downloads/

Situation_Unterinntal_2004.pdf (last access: 5 February 2009), 2005.

Vergeiner, I. and Dreiseitl, E.: Valley Winds and Slope Winds Observation and Elementary Thoughts, Meteorol. Atmos. Phys., 36, 264-286, 1987.

Verkehrsclub Österreich: Verkehr ist wachsendes Gesundheitsproblem, available at: http://www.vcoe.at/images/doku/ VCOeFactsheetGesundheitundVerkehr.pdf (last access: 5 February 2009), 2004.

Weber, A., Schatzer, D., Schoeler, F., Poellmann, A., and Schwaninger, C.: Luftgüte in Tirol - Bericht über das Jahr 2005, available at: http://www.tirol.gv.at/uploads/media/ Jahresbericht-2005.pdf (last access: 5 February 2009), 2005.

Wotawa, G., Seibert, P., Kromp-Kolb, H., and Hirschberg, M.-M.: Verkehrsbedingte Stickoxid-Belastung im Inntal: Einfluss meteorologischer und topographischer Faktoren, Endbericht zum Projekt Nr. 6983 Analyse der Schadstoffbelastung im Inntal des Jubiläumsfonds der Österreichischen Nationalbank, available at: http://www.boku.ac.at/imp/envmet/Inntal-Bericht.pdf (last access: 5 February 2009), 2000.

Zaengl, G.: A reexamation of the valley wind system in the Alpine Inn Valley with numerical simulations, Meteorol. Atmos. Phys., 87, 241-256, 2004. 